\title{
Secular, singular and self-expression? Religious freedom in Australian and New Zealand education.
}

\author{
Maxine Evers \\ Lecturer, UTS Faculty of Law \\ Dr Sally Varnham \\ Associate Professor, UTS Faculty of Law
}

\section{Introduction}

Why is that racist? Why is it discriminatory? It's very simple: people like some things but don't like other things. Some of us like blondes, some of us like brunettes. Some of us like Fords, some of us like Holdens. Why it is xenophobic just because I want to make a choice? If I want to like some people and not like other people that's the nature of the beast. ${ }^{I}$

The description of Australia and New Zealand as multicultural societies conjures up a snapshot of a community of adults and children from different ethnic backgrounds living together in a harmonious and tolerant environment. Why then do we see reports of events such as the one surrounding this statement in a daily Sydney newspaper? They indicate that perhaps the picture of cultural harmony is not altogether true today and that it would be unrealistic to ignore the stirrings within the community. The reality is that, in the context of education and society, schools in Australia and New Zealand are increasingly being challenged to rethink long held ideas of freedom and equality to incorporate and embrace the freedoms required by the new diversity.

$1 \quad$ Mr Sremchevich, President of the Camden/Macarthur Residents' Group opposing the setting up of a Muslim school in Camden, NSW. Sydney Morning Herald 2008. Catholics Welcome, Muslims not. September 9. www.smh.com.au/news/national/catholics- welcome-muslims-not (accessed March 18, 2009). 
There is no doubt that all children, regardless of ethnicity, have a right to education. Pursuant to international conventions ${ }^{2}$ the right to education is contained, in Australia, within state and territory legislation, ${ }^{3}$ and in New Zealand, in the Education Act 1989 (NZ). ${ }^{4}$ The right to educate set out in domestic legislation embraces the choice between government schools, private schools, and, in New Zealand, integrated schools. ${ }^{5}$ The changing nature of society means that increasingly the focus is on educators to incorporate and celebrate ethnic, religious and cultural differences within school communities. However, while all statutes make some provision for the choice of education provider, they are uniformly silent on the place of religious belief within that right.

The absence of any legislative responsibility on the state to respect the right of parents to have their children educated in accordance with their religious beliefs may go part way towards explaining why, as evidence suggests, larger numbers of parents in Australia and New Zealand are choosing to educate their children at home, giving religious convictions as their motivation. ${ }^{6}$

In Australia, for Catholic parents, there is the option, in most communities, of choosing a Catholic education for their children. To a lesser extent, other religions, including Anglican,

$2 \quad$ Article 26, Universal Declaration of Human Rights; Article 13, United Nations Convention on Economic, Social and Cultural Rights; and Articles 28 and 29, United Nations Convention on the Rights of the Child.

3 For example, s 4 Education Act (NSW), s 3 School Education Act 1999 (WA), s 7 Education Act 2004 (ACT). s 3 Education Act 1989 (NZ).

Pursuant to the Private Schools (Conditional) Integration Act 1975 (NZ).

For a comprehensive discussion of home education in Australia and New Zealand see Varnham, S. 2008. My home, my school, my island: home education in Australia and New Zealand. PUBLIC SPACE: The Journal of Law and Social Justice, 2:3: 1-30, quoting Harding, T., Farrell, A. 2003. Home Schooling and Legislated Education. Australia and New Zealand Journal of Law and Education. 8, 128; and for the UK see Monk, D. 2003. Home Education: A Human Right? Evaluation and Research in Education 17:2-3: $157-166$. 
Jewish and Christian, provide schools. There are also a few independent schools based on a philosophy and practice of teaching and learning rather than religious or spiritual beliefs, such as Montessori and Steiner. In reality, there is very little choice of education provider for ethnic and religious groups who are outside the mainstream in Australian society. This fact is leading to increasing calls by members of these different ethnic groups to establish schools in which the teaching and school practices embrace the particular religious beliefs of those communities.

In New Zealand, the education system is, in common with Australia, free, compulsory and secular. Pursuant to the Education Acts 1964 and 1989 New Zealand children between the ages of 6 and 16 must attend state schools, private schools and integrated schools. ${ }^{7}$ Integrated schools, generally previously private denominational schools, receive a large measure of government funding while still retaining their 'special character'. Schools which are totally classified as 'private schools' and which may also have religious affiliations also receive some government funding, though to a much lesser degree.

Attention is now being given to controversies surrounding religious freedoms and choice in education, and to what lies beneath them. There are two factors at work. First, the general trend towards secularism in the society in general, and secondly, the significant increase in population of ethno-religious groups. In the 1901 census in New Zealand, 1 in 30 people did not give a religious affiliation. A century later, in 2001, 4 in 10 did not specify a religious affiliation. ${ }^{8}$ In Australia, since 1971 when the census included a new category for religious affiliation, the percentage of persons stating they have no religion has increased to

$7 \quad$ Provided for in the Private Schools (Conditional) Integration Act 1975 (NZ).

$8 \quad$ http://www.stats.govt.nz/products-and-services/Articles/census-snpsht-cult-diversity -Mar02.htm. 
aprroximately $16 \%$ in 1996 and $2001 .^{9}$ Questionably, this secularism is leading to a much greater concern with the place of religion and religious observances in areas of public life, of which education is an integral part. This view is supported by Rishworth who says that the rising potential for conflict is due to several factors connected to 'the decline in mainstream religious belief and a corresponding rise of secularisation'. In discussing, in particular, the New Zealand situation, he writes that we may be approaching the end of the current benign tolerance of religious self expression. The view of the place of religion in society as 'harmless and inconsequential ${ }^{10}$ may now be countered by a new suspicion of fundamentalism and a fear of religious extremism following $9 / 11$ and the other catastrophic events which have followed. Certainly, this would be indicated in Australia by the negative community responses to the plans for a Muslim school in Camden in rural New South Wales (discussed below). ${ }^{11}$ Just as more citizens are opting out of established religions, the increase in immigration in recent years has meant that there is the emergence of ethno-cultural religion as a significant issue in society. Events such as the Cronulla riots ${ }^{12}$, racially-based threats and damage to buildings such as mosques are publicised and debated on an ad hoc basis. Such challenges to the harmony of our communities are felt by educators whose objectives are to assist and encourage young people to achieve their full potential to contribute to a society characterized by tolerance and understanding.

\footnotetext{
$9 \quad$ ABS Year Book, 2006:

http://www.abs.gov.au/websitedbs/D3310114.nsf/home/year+book+products. at the Legal Research Foundation's conference The New Zealand Bill of Rights Comes of Age. July 27-28, in Auckland, New Zealand.

11 Sydney Morning Herald. 2008. Catholics Welcome, Muslims not. September 9. www.smh.com.au/news/national/catholics- welcome-muslims-not (accessed March 18, 2009).

12 A series of incidents, including fighting, assaults, dam age to property and attacks on Police involving groups of young people of Middle Eastern backgrounds and local residents of Cronulla, a Sydney beachside suburb, which took place in December 2005.
} 
This paper overviews some of the questions now arising in relation to schooling and religious diversity. The questions are all necessarily intertwined. They arise in the context of:

1) The secular nature of state education systems in both Australia and New Zealand. In Australia this secularism is contained in the education acts of all state and territories and is constitutionally embodied in Section 116 of the Commonwealth of Australia Constitution - known as 'the establishment clause'. In New Zealand, the secular clause is now contained in the section 77 of the Education Act 1964 (NZ). ${ }^{13}$ Inevitably, any discussion of secular education gives rise to questions relating to the extent to which religious practices may be incorporated within state schools;

2) The controversies, particularly in Australia, which surround, first, the state funding of 'singular' or church schools, and secondly, the desire of particular minorities to establish faith schools which adhere to values and deliver instruction in accordance with their cultural and religious beliefs. In recent times, the attempts by the Islam community to establish schools has received even more attention than earlier attempts to build places of worship. In one case a local resident said Muslims were 'incompatible with the local community"14;

3) In any event, the extent to which religious freedom arises as an issue in schools.

In general terms, this article considers the rights of school students to practice religious beliefs and to express their beliefs within the frameworks constructed by governments through legislation and funding.

\section{Secular}

\footnotetext{
13 This section and others of the 1964 remain in force, not having been amended or repealed by the Education Act 1989. Sydney Morning Herald. 2002. Cheers as Islamic School rejected. 28 May.
} 
While the state school systems of both countries are expressed to be secular, ${ }^{15}$ there is no provision for separation of Church and State in either the New Zealand Constitution Act 1986 or the Commonwealth of Australia Constitution formulated in 1900. However Section 116 of the Commonwealth of Australia Constitution provides, in common with the US Constitution, an 'establishment' clause:

The Commonwealth shall not make any law for establishing any religion, or for imposing religious observance, or for prohibiting the free exercise of any religion ...

However, in variance with the US, this clause has not been interpreted to require a separation of church and state. ${ }^{16}$ The High Court of Australia considered the issue of separation of church and state in 1981 in the DOGS case, Attorney-General (Vic); Ex rel Black v The

Commonwealth. ${ }^{17}$ The hearing of this matter was the culmination of a long ranging and heated controversy, begun in the 1950 s, as result of government actions relating to Commonwealth funding of private schools. It was held (Murphy J dissenting) that grants by the Commonwealth to states to assist educational activities of non-government schools, including denominational schools, were not a breach of s 116. Mason J, referring to the Australian citizenry at that time as consisting of '... Non-conformists and Roman Catholics who had suffered from religious discrimination in their homelands and were devoutly opposed to its resurgence in the colonies' explained the insertion of s 116 thus: $:^{18}$

15 Set out in Australia in state and territory legislation, for example, s 30 Education Act 1990 (NSW), s 2.2.10 Education and Training Reform Act 2006 (Vic), s 68(1) School Education Act 1999 (WA), s 28 Education Act 2004 (ACT). In New Zealand, ss 77 \& 78 Education Act 1964 (NZ).

16 In the US there are plethora of cases relating to religious observances and religious freedom in schools, based on the 'establishment' clause of the US Constitution, beginning with the original prayer in schools cases such as Engel $v$ Vitale (1962) 370 U.S. 421 and Abington School District v Schempp (1963) 374 U.S. 203.

17 Attorney-General (Vic); Ex rel Blackv The Commonwealth (1981) 146 CLR 559 (DOGS Defence of Government Schools).

18 Attorney-General (Vic); Ex rel Blackv The Commonwealth (1981) 146 CLR 559, per Mason J at para 15. 
To the Australian colonists the preservation of religious equality was perhaps more important than the preservation of religious freedom for the simple reason that they had experienced the disadvantages of religious inequality and it posed a more immediate threat than the absence of religious freedom.

Wilson J of that Court described the level of government funding to religious schools in 1979, immediately preceding that case, as: ${ }^{19}$

\begin{abstract}
In the same year, there were a total of 2,002 non-government schools which received financial assistance from the Commonwealth under the legislation in question, of which 1,965 were schools which acknowledged some religious character either by way of affiliation with a religious body or simply as Christian schools. Of these, 1657 schools were conducted by the Roman Catholic Church.
\end{abstract}

The controversy relating to Commonwealth funding of non-government schools, of which denominational schools are a hugely significant part, continues to simmer. ${ }^{20}$

This debate aside, the freedom to practice one's religion receives different legislative treatment in both countries, with New Zealand having a specific right guaranteed by the New Zealand Bill of Rights Act 1990 (NZ). ${ }^{21}$ One Australian state and one territory, namely Victoria and the Australian Capital Territory, have enacted human rights legislation which similarly make provision for freedom of religion. ${ }^{22}$

In New Zealand there has been provision for secular education since the first Education Act 1877 (NZ). Currently, the Education Act 1964 (NZ) provides that teaching shall by 'entirely of a secular nature'. ${ }^{23}$ Within that section however is provision that classes, or the school as a whole, may be closed for defined periods for the purpose of religious instruction or religious

\footnotetext{
Attorney-General (Vic); Ex rel Black v The Commonwealth (1981) 146 CLR 559, per Wilson $\mathrm{J}$ at para 20.

20 For a discussion, see Buckingham, J. 2000. School Funding for All: Making Sense of the Debate over Dollars. Issue Analysis 17. 12 October.

$21 \mathrm{~S} 13$ provides for freedom of thought, conscience and religion.

22 s 14, Charter of Human Rights and Responsibilities 2006 (Vic) and s 14, Human Rights Act 2004 (ACT).

$23 \mathrm{~s} 77$ Education Act 1964 (NZ), preserved by the Education Act 1989 (NZ).
} 
observances. School boards of trustees ${ }^{24}$ and principals can agree to offer religious instruction given by voluntary instructors. ${ }^{25}$ In additional to this provision, the Minister (of Education) may authorise supplementary religious instruction if the majority of parents indicate a wish for it, if the school board of trustees is in agreement and if the Minister is of the view that this will not cause detriment to the normal school curriculum. ${ }^{26}$ The opportunity to attend regular scripture classes is often determined by the availability of scripture teachers. The choice of types of religious education offered to students is piecemeal and provided on an ad-hoc basis, with the supply of available volunteer "teachers" taking precedence over the demand, interests or needs of students.

Parents on behalf of their primary school children and teachers may opt out of religious instruction and observances by conveying this wish in writing to the school principal. ${ }^{27}$ The opting out provision of the Act requires that the principal be satisfied that the parent or student has requested release from tuition for "sincerely held religious or cultural views". ${ }^{28}$ In cases where the parent has made the request, the principal must take all reasonable steps to ascertain the student's views on the matter. ${ }^{29}$

The legislative provision for religious education puts the onus on students who wish to opt out rather than the obligation being on the students who wish to accept the offer of religious teachings. Those who opt out are required to undertake private study when scripture classes are held. The potentially discriminatory aspect of the 'opt out' provision has been largely responsible for debate regarding the part religion should play in New Zealand state schools.

\footnotetext{
24 Since 1989 in New Zealand each state school is administered by a locally elected board of trustees pursuant to s 75, Education Act 1989 (NZ).

s 78 Education Act 1964 (NZ).

s 78A Education Act 1964 (NZ).

ss 78, 79 Education Act 1964 (NZ), preserved by the Education Act 1989 (NZ).

s 25 A Education Act 1989 (NZ).

s 25A (3) Education Act 1989 (NZ).
} 
This debate now includes the potential for breaches of the freedoms of expression, religion and freedom from discrimination guaranteed by the New Zealand Bill of Rights Act 1990. In response the Ministry of Education in 2006 proposed guidelines for the practice of religion in schools. ${ }^{30}$ These guidelines aimed to replace the 'opt out' provision with an 'opt in' provision, and to discontinue various practices such as prayers at school assemblies and Maori Christian Karakia. $^{31}$

The proposals were abandoned within a relatively short time, leaving the status quo in place, namely, that any decision relating to the part religion will play in public schools, is, within the confines of the Education Act 1964 (NZ) and the Education Act 1989 (NZ), left to individual school boards of trustees. The debate has not gone away however. In 2007, the Human Right Commission (Te Kahui Tika Tangata) published, in its "10 Human Rights Cases - 2007", 32 an account of a case involving a six year old child whose parents had chosen to opt him out of a period of religious instruction within the school day. The complaint of discrimination was prompted by the school failing to provide supervision for the child during that time. This matter was resolved through a mediation process but the Human Rights Commission noted that this is now an issue which is frequently coming before them not only in this context in relation to religious instruction in schools generally. ${ }^{33}$

\footnotetext{
$30 \quad$ Ministry of Education submission to the Education and Science Select Committee on Religious Instruction and Observances in State Schools, 2006.

$31 \quad$ Maori incantation or prayer which acknowledges a spiritual presence.

32 www.hrc.co.nz/hrc new/hrc/cms/files/documents/06-Dec-2007 21-06

-46_10_HR_Cases_2007.pdf (accessed April 29,2009).

Resourced from www.hrc.govt.nz. The Human Right Commission has issued some Frequently Asked Questions for School Boards of Trustees on this issue. In addition it is sponsoring a series of 'Diversity Forums', the most recent in Auckland in August 2008 which explore a wide range of issues relating to the multicultural, multi-ethic and multi-faith society of New Zealand now.
} 
In Australia, in schools within the state education systems, general religious education is permitted within the meaning of secular instruction. ${ }^{34}$ For example, section 30 of the Education Act 1990 (NSW) states:

In government schools the education is to consist of strictly non-sectarian and secular instruction. The words "secular instruction" are to be taken to include general religious education as distinct from dogmatic or polemical theology.

Although state schools are secular in their nature and purpose of teaching and learning, they allow for optional special religious education where students are engaged in scripture classes taken by volunteer members of various religions. The opportunity for students in government schools to attend these classes is provided for in the relevant legislation. In NSW also, section 32 of the Education Act 1990 (NSW) provides that some lesson time is to be allowed for "religious education of children of any religious persuasion". Section 33 provides that a child is not required to have "any general religious education or special religious education" if the parent objects. ${ }^{35}$

It is clear in both Australia and New Zealand that, just as the role and function of religion in society generally is coming under more scrutiny, so it is in schools. While there is, unlike the United States, an absence of jurisprudence relating to the exercise of religious freedoms, such as prayer, in schools, ${ }^{36}$ there are some indications that things may be changing. Recently in New Zealand: 66 School Education Act 1990 (WA), s 102(1) Education Act 1972 (SA), ss 28 \& 29 Education Act 2004 (ACT), ss 34(2)-(3) Education Act 1994 (Tas). Education Act 1999 (WA); s 73 Education Act (NT); Education (General Provisions) Act 2006 (Qld);

36 Education Act 1972 (SA) provide for religious education. Large numbers of cases there are founded on allegations that religious practices in schools are in breach of the establishment clause in the First Amendment to the US Constitution. See n16. 
- $\quad$ There has been reported outrage by some parents at Seatoun Primary School

Wellington, over a lunchtime "KidsKlub", a Christian Club, being run by other parents at the school; ${ }^{37}$

- A complaint has been taken to the Human Rights Commission about Victoria Avenue Primary School in Auckland including the Lord's Prayer in its daily assemblies, ${ }^{38}$

- $\quad$ There have been questions and discussion relating to whether Maori Christianity and spirituality generally, in the form of prayers in Maori ceremonies, should be allowed in schools; ${ }^{39}$

- Questions have been asked concerning the proposed building of Muslim prayer rooms in schools. ${ }^{40}$

And, in Australia:

- An exclusive private school in Brisbane refused to enrol a Sikh student unless he conformed with the school uniform code by removing his turban and cutting his hair. Faced with a strong stance on the part of the school, the student's parents took a complaint to the Queensland Anti-Discrimination Tribunal; ${ }^{41}$

- There has been reported concern over Christian youth ministries linked to the Hillsong Church recruiting members at public schools through free lunchtime concerts and

\footnotetext{
37 For example: New Zealand Herald. 2005. Religious Club Divides State School. June 9. www.nzherald.co.nz/nz/news (accessed April 28). December 22. See below n 40. Motu. www.hrc.co.nz/report/chapters/Chapter09/religion.02.html (accessed April 28). 
barbecues, on the basis that such practices are contrary to the secular and non-sectarian nature of public schooling; ${ }^{42}$

- There is reported opposition by Melbourne universities to Muslim university students requests for changed class times so they can attend congregational prayers. In response the university has said "We are a secular institution ... and we need to have a structured timetable"; 43

- Headlines, such as "Cheers as Islamic school rejected" $" 44$ have captured the protests of local residents of Camden, a semi-rural suburb on the outskirts of Sydney, against the establishment of an Islamic school. The local council rejected the application on the basis of planning grounds. However the concern of many residents was demonstrated by the reported number of objections to the proposals. One resident was quoted as saying: 'The fact is that Camden has been a strongly white community for a long time and the people here are scared. I'm not a racist person - that just a statement of fact. ${ }^{45}$

These incidents and controversies point to the fact that the tensions within society are mirrored within education institutions. It is undeniable that the increasingly larger ethnic and religious minority are, in the rights culture of today, becoming more insistent and vocal in calling for a greater acceptance and accommodation of their requirements. While this is as it should be, it does pose challenges relating to their accommodation within the secular education systems in terms of religious practices within schools.

\section{Religious practices in schools}

$42 \quad$ Sydney Morning Herald. 2008. Hillsong's schools recruitment drive. September 9, http://www.smh.com.au/news/national/hillsongs-schools-recruitment (accessed April 10, 2009).

43 The Australian. 2008. Muslims want uni classes to fit prayer times. February 25.

$44 \quad$ Sydney Morning Herald. 2008. May 28, 1 \& 4.

$45 \quad$ Sydney Morning Herald. 2008. May 28, 4. 
In New Zealand, in the view of Rishworth, the trend is towards new generations of secular New Zealanders questioning long standing laws and practices in education, such as schools producing religious pageants. ${ }^{46}$ As he explains, such questioning is more properly described as freedom 'from' religion rather than freedom 'of' religion. Despite anecdotal evidence however, there are thus far no such reported cases in New Zealand. To date the only religion in schools case in New Zealand arose obliquely as a challenge to the power of a school in relation to suspension procedures. In Rich v Christchurch Girls' High School Board of Governors (No 1) and (No 2). ${ }^{47}$ Wendy Rich had objected to the school's requirement of attendances at religious services and had not only failed to attend these services but had distributed a circular calling on students to walk out of assembly during the religious section. She was expelled from the school for 'gross misconduct or incorrigible disobedience', the wording required by the Education Act 1964 (NZ). The Court of Appeal firmly upheld the decision of the school thus reinforcing the school's authority. This case arose before the passing of the New Zealand Bill of Rights Act 1990 (NZ) and it is open to conjecture whether an argument by the plaintiff based on the right to freedom of religion in s 13 or the right to freedom of expression, in s 14, would have been more successful. However, because the rationale behind the decision was the prevention of disruption and the maintenance of safety in the school community, any limitation on Wendy's rights may have been held, under s 5 , to be ' ... demonstrably justified in a free and democratic society'.

\footnotetext{
46 Rishworth, P. 2007. The Religion Clauses of the New Zealand Bill of Rights. Essay presented at the Legal Research Foundation's conference The New Zealand Bill of Rights Comes of Age. July 27-28, in Auckland, New Zealand, 3.

47 [1974] 1 NZLR 1 and [1974] 1 NZLR 21 respectively.
} 
If the trend identified by Rishworth ${ }^{48}$ is to continue, New Zealand courts may before too long be faced with cases relating to religious practices in schools.

In Australia there are a small number of reported cases relating to religious practices in schools. In Benjamin $v$ Downs ${ }^{49}$ a father objected to certain prayers being recited at the assemblies of the public school which his child attended. He argued that this amounted to the teaching of biblical studies which was not permitted under the existing Public Instruction Act 1880 (NSW). ${ }^{50}$ He said that schools should teach about Christianity but not teach Christianity. Helsham $\mathrm{J}$, in rejecting the father's argument, made the following comments about religious observances in New Wales schools: ${ }^{51}$

... the teaching of prayers in class to be said or sung or other activities of a
religious nature at assembly would not offend the Act provided the content of
the prayers or the nature of the other activities could be said to be non-sectarian
and not falling within the prohibition of teaching dogmatical or polemical
theology.

Importantly he added that because such religious practices were caught by section 18 of the Act, parents had the right to object in which case the pupil concerned would not be required to take part.

The second challenge was framed as an allegation of discrimination. $A$ obo $V$ and $A v N S W$ Department of School Education ${ }^{52}$ arose as a complaint by a Jewish father to the New South Wales Anti-Discrimination Tribunal. The complainant objected to prayers in assembly, the children's involvement in a nativity scene, and participation in Christmas concerts and Easter

\footnotetext{
48 Rishworth, P. 2007. The Religion Clauses of the New Zealand Bill of Rights. Essay presented at the Legal Research Foundation's conference The New Zealand Bill of Rights Comes of Age. July 27-28, in Auckland, New Zealand, 3.

$49 \quad$ [1976] 2 NSWLR 199.

50 The relevant provisions are repeated in ss $32 \& 33$ of the current Education Act 1990 (NSW)

51 [1976] 2 NSWLR 199.

52 [2000] NSWADTAP 14
} 
events, such as the exchange of easter eggs. The NSW Administrative Appeals Tribunal dismissed the complaint. It found that showing that the children had been exposed to Christian teaching was not sufficient of itself to establish discrimination. The panel noted: 'The respondent's conduct occurred in spite of the children's religious practices, not because of them .....$^{53}$

In the Australian context, it is of interest to conclude this discussion with a proposal from the Rudd Labour Federal Government. The Government, elected in November 2007, announced that it intended to expand the previous Liberal Government's "Chaplaincy in Schools Program" to fund the employment of secular counsellors in schools where religious chaplains could not be found. This proposal has met with opposition and among its suggested flaws are, firstly as there are no enough chaplains to fill the positions, secondly, non-religious guidance counsellors and education psychologists may be better trained to act in that capacity and should not be considered suitable only if a religious chaplain is not available and thirdly, such a program discriminates against non-believers and government schools. These essentially practical considerations aside, it is not hard to imagine a challenge to such a policy under s 116 of the Constitution. There is also the issue of federal intervention into state rights by the use of the 'corporations' power under the Constitution. As noted by Kirby $\mathrm{J}$ of the High Court of Australia in New South Wales $v$ Commonwealth (known as the WorkChoices case), the "expanding cohort of private schools" that are

\footnotetext{
$53 \quad$ [2000] NSWADTAP 14, at para 18.
} 
incorporated means that traditional state matters, such as education, may be transferred to the Commonwealth. ${ }^{54}$

If the potential is increasing for challenges within our secular systems to those requiring freedom 'from' religion, does the same go for religious groups requiring religious singularity and exclusivity within the education system?

\section{Singular}

The essential questions relating to the 'singularity' of sectarian or denominational schools are separate but obviously closely related. They concern: first, the extent to which public funds should be applied to exclusively denominational schools; ${ }^{55}$ secondly, the establishment of particular religious schools; thirdly, whether it should be a condition of public funding that these schools accept students outside that particular religion; and fourthly, to what extent, if any, may these schools impose restrictions on the enrolment and attendance of students from outside the sect, creed or religion. Funding and constitutional issues aside, implicated within these questions will inevitably be the exercise of fundamental rights and freedoms including the right to be free from discrimination.

Religion, simply defined, includes traditional church based teachings and more recentlyintroduced beliefs and practices, including Buddhism, Hinduism and new Christianity. The establishment and maintenance of secular schools in Australia by state and territory

New South Wales $v$ Commonwealth [2006] HCA 52 at 539. This case concerned the division of power between state and federal governments pursuant to s 51 of the Constitution. A 5:2 majority of the High Court of Australia upheld the Workplace Relations Amendment (Work Choices) Act 2005 (Cth) ('Work Choices Act') as validly enacted under the Commonwealth corporations power.

55 The application of public funds to private schools in Australia is a complex, thorny and ongoing debate which is outside the scope of this paper. 
governments does not cover the field in relation to the provision of education. Secular schools co-exist with non-government or private schools, many of which are established and maintained by religious entities. For example, in Australia, approximately $30 \%$ of schools are non-government, large numbers of these being denominational and predominantly Catholic. ${ }^{56}$

Obviously church schools provide a service to government and the community because they offer education that otherwise the state would be obliged to supply. And it is on that basis that public funding for these schools and the teaching by them of religion additional to the curricula is justified. The Code of Canon Law of the Roman Catholic Church prescribes: "The Church has a right to establish and direct schools of any discipline, type, and level."57

However, as the world watched Sydney during World Youth Day in July 2008, the Pope, in a sign of ecumenism, met with leaders of other religions including Islam, Judaism, Hinduism, Buddhism and the ancient Zoroastrians. On the issue of religious freedom, he said: ${ }^{58}$

In Australia, as elsewhere, religion has been a motivating factor in the foundation of many educational institutions, and rightly it continues to occupy a place in school curriculum today.

A policy of 'singularity' practised by a sectarian school was the subject of a 1999 complaint to the Equal Opportunity Tribunal of Western Australia. In Goldberg v Korsunski Carmel School ${ }^{59}$ the complaint was of discrimination on the grounds of religious conviction pursuant to the provisions of the Equal Opportunity Act 1984 (WA). It did not relate to failing to admit the son of the complainant but rather to a number of restrictions placed on his admission and attendance on the basis that he was not regarded as Jewish. Carmel School is a private school which had been established to provide Orthodox Jewish students with a Jewish education

\footnotetext{
56 The website of Christian Research Association states that non-government represent 28\% of all Australian schools. See http://www.cra.org.au/pages/00000088.cgihttp.

57 Can. 800.1- Code of Canon Law - www.vatican.va/archive/ENG1104/_ P2N.HTM (accessed August 15, 2008).

Daily Telegraph . 2008. Bring religion into classrooms, says Pope. July 19, 1.

(1999) EOT (WA).
} 
pursuant to orthodox principles. Originally only Orthodox Jewish children were able to be enrolled in the school but this changed in 1992 following a resolution by the school board allowing the enrolment of children of any faith. The restrictions were that non Jewish students were not eligible for fee assistance and scholarships, and were not able to be head boy. ${ }^{60}$ It was these conditions which the complainant objected to. In their defence the school relied on section 73(3) of the Equal Opportunity Act 1984 (WA) which allowed such denominational schools to discriminate in favour of members of the particular religion provided such acts were done 'in good faith'. The Tribunal found that the school was able to rely on this section as it was acting generally within its stated objectives in providing an education which was in accordance with Orthodox Judaism. It found that as the school was treating all non-Jewish students in the same way it had not discriminated against the complainant's son.

The 'singular' policy was also an issue in Tasmania with some Catholic schools indicating that they intended to apply for an exemption from the Anti-Discrimination Act 1998 (Tas). The objective was to ensure a continuing "strong Catholic ethos and vision". ${ }^{61}$

Controversy over establishment of particular religious schools was seen in Australia recently in the community reaction to, and the local Council's determination to reject, the proposed foundation of a school in rural New South Wales by a religious group. ${ }^{62}$ This controversy, which, it could be said, reflects shamefully on Australian society, could arguably have more to do with post 9/11 suspicion and the challenges such beliefs pose for western culture rather than religion. It strongly points to the fact that Australian education is not immune from the threats, perceived or real, which are evidenced abroad by headlines such as: “British Varsities' Islamic

\footnotetext{
60 Though this latter restriction was removed, but under certain conditions relating to the leading of prayers, previously done by the head boy.

61 National Nine News. 2007. Catholic schools in bid to ban non-Catholics. May 31. http://news.ninesmsn.com.au/article.aspx (accessed 9 April).

62 Referred to earlier, see nn $1 \& 14$.
} 
centres 'breeding extremism: Report claims that generous Arab donors use centres to spread anti-Western agenda,", ${ }^{63}$ In the Camden situation the local council declined planning permission for the Quranic Society to build an Islamic school. The Society challenged the refusal in the Land and Environment Court in April 2009. At the time of writing this paper, the decision had not been handed down. Planning considerations aside, it is of interest to consider the chances of success the school authorities could have in an action under the AntiDiscrimination Act 1977 (NSW). They would have to prove, under s 7(1) (a) that they had been treated less favourably in the same or in circumstances which are not materially different to the manner in which the Council treats or would treat others of a different race. Given the planning rationale for the Council's decision, this comparator provision would probably prove insurmountable, unless it could be shown that the giving of simultaneous approval for the Catholic school to be established was 'in similar circumstances'. Should a complaint be substantiated, the Anti-Discrimination Tribunal could under s 108 of the Act make an order requiring the Council to cease the discriminatory conduct.

In New Zealand the education system has greater uniformity and fewer complexities than in Australia. ${ }^{64}$ With the passing of the Private Schools (Conditional) Integration Act 1975 (NZ), the government offered funding to former private schools to integrate into the state school system. In return for funding, non-government schools must enter into an integration agreement that enables the school to maintain its "special character" and to provide preference or enrolment to parents of students who "have a particular or general philosophical or religious

\footnotetext{
63 Straits Times, Singapore. 2008. April 18, 14. The article discusses a report of a study appearing in the UK'S Daily Telegraph.

64 This is due to the fact that there is one national Education Act whereas in Australia education in each state and territory is provided according to its own Act.
} 
connection". ${ }^{65}$ The school then offers remaining places to non-connected students. To date there have been no judicial challenges relating to placement in integrated schools.

Part of the curricula in Australia and New Zealand is to teach students the skills and knowledge to form a view, to be able to debate that view and to listen to the views of others. In the next section we consider the exercise of individual religious freedom and self expression within schools, and whether it may justifiably be limited in the interests of the school and wider community.

\section{Religious self-expression}

Religious expression may be manifested verbally, for example through prayer (as discussed above), or by way of dress, appearance and adornment. How is the freedom of young people to religious self-expression within schools regarded now?

In Australia, in the absence of a federal bill of rights or a bill of rights in the states and territories, with the exception of Victoria and the Australian Capital Territory (discussed below), the right to freedom of religion and freedom of expression are said to exist at common law. The right to freedom of expression was affirmed by the High Court in 1992 with the result that the common law treats such rights as liberties which exist unless limited or prohibited by law. ${ }^{66}$ In recent years, the Australian Capital Territory and Victoria have passed rights legislation which contains guarantees of freedoms of religion and expression. These are contained in sections 14 and 16, Human Rights Act 2004 (ACT), sections 14 and 15 Charter of Human Rights and Responsibilities Act 2006 (Vic). In terms of application, the Victorian

\footnotetext{
65 s 29 Private Schools Conditional Integration Act 1975 (NZ).

66 In Australian Capital Television Pty Ltd v Commonwealth (1992) 177 CLR 106, and affirmed in Coco v R (1994) 179 CLR 427.
} 
Charter states that it is 'unlawful for a public authority to act in a way that is incompatible with a human right or, in making a decision, to fail to give proper consideration to a relevant human right." ${ }^{67}$ Section 4 then contains a definition of 'public authority' which essentially means all bodies executing a public function. The conclusion that public schools are clearly within this definition is strengthened by the express exclusion of private schools. ${ }^{68}$ The ACT Human Rights Act makes provision for its application by way of section 40 inserted by section 7 of the Human Rights Amendment Act 2008 which came into force on $1^{\text {st }}$ January 2009. In this amendment, public education is expressly included within the definition of a 'function of a public nature'. ${ }^{69}$ This excludes private school education by implication.

Both pieces of legislation provide for limitations on the exercise of the guaranteed rights. The ACT Act states in its preamble: 'Few rights are absolute. Human rights may be subject only to the reasonable limits in law that can be demonstrably justified in a free and democratic society. One individual's rights may also need to be weighed against another individual's rights". In addition it contains a general provisions for the limitation of rights - “... that can demonstrably be justified in a free and democratic society. ${ }^{70}$ Among the factors to be taken into account in assessing the justice of any such restriction is whether there are 'any less restrictive means reasonably available to achieve the purpose the limitation seeks to achieve'. ${ }^{71}$

Section 4 of the 2008 amendment (inserting a new section 28(2) into the 2004 Act) details factors which may be considered as: the nature of the right effected, the nature, extent and purpose of the limitation, and the 'relationship between the limitation and the purpose.' This

\footnotetext{
67 s 38 Charter of Human Rights and Responsibilities Act 2006 (Vic). For a comprehensive discussion of the Charter see Williams G. 2006. Critique and Comment The Victorian Charter of Human Rights and Responsibilities: Origins and Scope. Melbourne University Law Review, 27-52.

68 s 4 Human Rights Act 2004 (ACT).

$69 \quad$ S 40A(3)(b)(iv) Human Rights Act 2004 (ACT).

$70 \quad$ s 28 Human Rights Act 2004 (ACT).

$71 \quad$ s 28 (d) Human Rights Act 2004 (ACT).
} 
limitation provision is mirrored in section 7(2) of the Victorian legislation, which provides, in addition, in relation to freedom of expression:

s 15(3) Special duties and responsibilities are attached to the right of freedom of expression and the right may be subject to lawful restrictions reasonably necessary-

(a) to respect the rights and reputation of other persons; or

(b) for the protection of national security, public order, public health or public morality.

Both provisions could clearly be taken to justify restrictive school rules and regulations, introduced for the purposes of the welfare of the school community and education free from disruption.

Both the ACT and Victorian statutes guarantee to all persons the right of self expression in the usual manner, such as orally or in writing, but also 'in another medium chosen by him or her'. This provision is in line with jurisprudence elsewhere. In the school context it is consistent with the much-quoted US case, Tinker $v$ Des Moines Independent School District, ${ }^{72}$ in which the Supreme Court held that 'expression' may include dress, appearance and adornment. In deciding that a school could not prevent students wearing black armbands to protest the Vietnam War, the Court stated: ${ }^{73}$

It can hardly be argued that either teachers or students shed their constitutional rights to freedom of speech or expression at the schoolhouse gate'.

Importantly however the court was careful to add that the exercise of the right could be restricted in cases where it was likely to cause material or substantial disruption of class work, in the school generally or in relation to the rights of others.

\footnotetext{
$72 \quad 393$ U.S 503, 89 S. Ct. 733, 21 L.Ed 2d 731 (1969).

$73 \quad 393$ U.S 503, 89 S. Ct. 733, 21 L.Ed 2d 731 (1969), at p 737.
} 
In addition to the statutory justifiable limitation provisions, these words provide a strong argument for schools in limiting individual rights in the interests of the safety and welfare of the whole school community.

With the exception of the two enactments in ACT and Victoria, citizens, and in this context, students, in the other states and territories of Australia must rely on the rights which exist at common law. It is unclear the extent to which these common law rights apply within schools but there is no evidence to suggest otherwise.

There is probably more likelihood, in most states of Australia at least, in the absence of statutory human rights, of an action being pursued on the basis of discrimination under state anti-discrimination or equal opportunity legislation other than under common law rights and freedoms.

All states and territories have legislation which prohibits discrimination in education on a number of grounds. Some expressly set out religious belief or activity as one of the grounds or characteristics for unlawful discrimination. ${ }^{74}$ Others contain only a prohibition on the grounds of race. ${ }^{75}$ In New South Wales, an complaint of discrimination on the grounds of religion, could be brought within s 7 which states that: 'For the purposes of subsection (1) (a) and (b), something is done on the ground of a person's race if it is done on the ground of ... a characteristic that appertains generally to persons of that race or a characteristic that is generally imputed to persons of that race'. ${ }^{76}$

\footnotetext{
74 s 7(1) (i) Discrimination Act 1991 (ACT); s 6(j) Equal Opportunity Act 1995 (Vic); s 7 (i) Anti-Discrimination Act 1991 (Qld); s 61 Equal Opportunity Act 1984 (WA); s 19 (m) Anti-Discrimination Act (NT).

75 s 51 Equal Opportunity Act 1984 (SA), ss 7 \& 17 Anti-Discrimination Act 1977(NSW).

$76 \quad$ Under ss 7 \&17, Anti-Discrimination Act 1977 (NSW):
} 
A vision of the potential for a claim of discrimination based on religious expression is afforded by the recent complaint to the Queensland Anti-Discrimination Board by the father of a Sikh student (referred to earlier in this paper). The student was required by the school to comply with the uniform code by removing his turban and shaving his hair. Before the matter was heard, it was settled with an apology from the school and payment of an undisclosed sum. The school has stated that they will review their enrolment practices to ensure they are 'aligned with the Anti-Discrimination Act' ${ }^{77}$ It is interesting to speculate on the reasons why the school abandoned its initially strong stance.

New Zealand, in common with the Australian Capital Territory and Victoria in Australia, and the UK, has rights guaranteed by the New Zealand Bill of Rights Act 1990 (NZ). It is important to note however that, while the Canadian Charter of Rights and Freedoms was used as in model in the formulation of the New Zealand Bill of Rights, it is not similarly entrenched as is the US Constitution. This is in common with the UK Human Rights Act 1990 and the ACT and Victorian legislation in Australia. The New Zealand Bill of Rights provisions are:

s 13: Freedom of thought, conscience and religion - Everyone has the right to freedom of thought, conscience, religion and belief, including the right to adopt and to hold opinions without interference.

s 14 Freedom of Expression -Everyone has the right to freedom of expression, including the freedom to seek, receive, and impart information and opinions of any kind in any form.

s 15 Manifestation of religion and belief - Every person has the right to manifest that person's religion or belief in worship, observance, practice, or teaching, either individually or in community with others, either in public or private.

In accordance with section 3 the Act applies to any acts done by the three branches of government as well as any person or body performing public function, power, or duty. For this

77 The Australian. 2008. School settles with Sikh boy's family over hair. September 2. www.theaustralian.news.com.au/story/ (accessed 9 March). 
reason the Act has been held to apply to the actions of public schools and integrated schools ${ }^{78}$ and arguably also to private schools as they are performing the public and statutory education function. ${ }^{79}$ The Act contains a provision that rights and freedoms may be curtailed: '... only to such reasonable limits prescribed by law as can be demonstrably justified in a free and democratic society'. In the New Zealand school context it is generally accepted that this section would act to justify a school's exercise of its powers to curtail the exercise of a right where it is necessary in the interests of school welfare and safety. ${ }^{80}$

\section{Conclusion}

This paper has considered some of the issues relating to the extent to which religious freedoms may be exercised within the education systems of the culturally diverse societies of Australia and New Zealand today. May religious instruction be rightly incorporated within a secular education system and if so, what spiritual beliefs should be incorporated? Should the public purse be applied to denominational education and if so, on what conditions? To what extent should individual students or groups of students be allowed manifestation of their religious beliefs within the public school system? While the contextual backgrounds of the issues are wide ranging, they all have their foundation in the fundamental right to freedom of religion. When may an individual's right to be educated in accordance with his or her religious beliefs and convictions be exercised, and when may it be curtailed in the interests of society as a whole? There are many tensions within a democratic and multicultural society which attempts to embrace the right of all persons to exercise individual freedoms whilst at the same time strives to maintain community peace.

\footnotetext{
$78 \quad$ Re Strip Search at Hastings Boys High School [1990-192] 1 NZBORR 480.

79 In relation to other private bodies conducting public or statutory function, Federated Farmers of New Zealand (Inc) v New Zealand Post Limited [1992] 3 NZBORR and TV3 Network Ltd [1993] 3 NZLR 435.

80 Rishworth, Paul. 1999. Search and Seizure in Public Schools. Paper presented at the New Zealand Law Society Education Law Seminar, October, in Auckland, New Zealand.
} 
There is no doubt that in both societies the increasing diversity in population means that the right to exercise religious freedom is advancing into all spheres of public life. Inevitably, to the extent to which religion, culture and ethnicity are intertwined, any challenges to limitations on religious freedoms will most likely be on the grounds of discrimination, under the human rights, anti-discrimination and equal opportunity legislation of New Zealand and the Australian states and territories. This has been the case thus far in Australia. The true value of human rights and anti-discrimination legislation however does not lie in its interpretation and application by the courts. Rather its effectiveness lies in the role it plays in educating all citizens, and in ensuring adherence to human rights by all sectors of the community, particularly government policy makers, legislators and public institutions.

Hopefully, the resolution may come, not through litigation, nor through formal policy and regulation, but by all people approaching these matters by way of principles of equal partnership, religious sensitivity and accountability. This could be, for example, through the promotion of organisations such as Together for Humanity, a Sydney project that brings together students from schools representing Islamic, Jewish, Anglican and Catholic backgrounds to discuss their beliefs and to plan sporting and other projects. ${ }^{81}$

Australia and New Zealand are both multicultural nations, committed to individual rights and freedoms which include embracing a diversity of religious beliefs and practices. The majority of people spend twelve of their most formative years in schools. It is therefore the manner in which educators and students behave towards each other which can set the model for the advancement of tolerance and harmony in society.

$81 \quad$ For a discussion of such a project see Sydney Morning Herald. 2008. A religious divide, but students find common ground. August 18. Also see Together for Humanity website http://togetherforhumanity.org.au/contact.php (accessed April 27, 2009). 


\section{References}

Buckingham, J. 2000. School Funding for All: Making Sense of the Debate over Dollars. Issue Analysis 17. October 12.

Harding, T., Farrell, A. 2003. Home Schooling and Legislated Education. Australia and New Zealand Journal of Law and Education, 8, 128

Human Rights Commission of New Zealand Report Human Rights in NZ Today Nga Tik Tangata O Te Motu. www.hrc.co.nz/report/chapters/Chapter09/religion.02.html

Monk, D. 2003. Home Education: A Human Right? Evaluation and Research in Education, 17:2-3: 157-166.

Rishworth, P. 2007. The Religion Clauses of the New Zealand Bill of Rights. Essay presented at the Legal Research Foundation's conference The New Zealand Bill of Rights Comes of Age. July 27-28, in Auckland, New Zealand.

Rishworth, Paul. 1999. Search and Seizure in Public Schools. Paper presented at the New Zealand Law Society Education Law Seminar, October, in Auckland, New Zealand.

Varnham, S. 2008. My home, my school, my island: home education in Australia and New Zealand. PUBLIC SPACE: The Journal of Law and Social Justice, 2:3: 1-30

Williams G. 2006. Critique and Comment: The Victorian Charter of Human Rights and Responsibilities: Origins and Scope. Melbourne University Law Review, 27-52. 